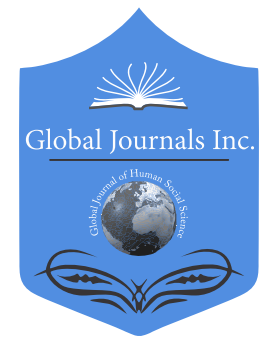

\title{
Burgeoning of Commercial Ornamental Plant Nurseries in Dar es Salaam City: Challenge and Future Prosperity
}

\author{
By Pastory, S. T, Francis, H. S \& Temu, G. S \\ Sokoine University of Agriculture Morogoro
}

Abstract- Commercial ornamental nurseries are popping up everywhere in the city of Dar es Salaam. However, as the city urbanizes, the commercial ornamental nurseries are confronted by several challenges of which are inadequately explored and documented. This research examines challenges, problems and explains the future prospects of commercial ornamental nurseries in the city of Dar es Salaam. The study adopted the case study design where the method for data collection relied on in-depth interviews and observation. Results revealed that ornamental plant dealers face several challenges such as; unsecured land tenure, which threaten the prosperity of the commercial ornamental nursery practices. Problems encountered are those related to plant pests, diseases management and inaccessibility of water for irrigation. On the other hand, commercial ornamental dealers get little support from the responsible city authorities in access land and management of pest and diseases. The study recommends that success of commercial ornamental nursery industry needs more support from different actors and policies together with capacity building among the commercial ornamental dealers.

Keywords: commercial ornamental nurseries, challenges, future prosperity.

GJHSS-B Classification: FOR Code: 070699, 070399

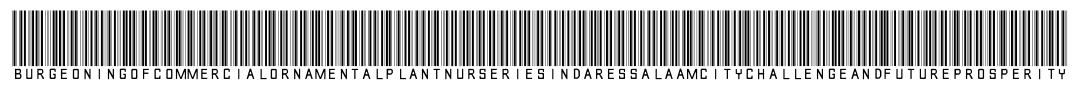

Strictly as per the compliance and regulations of:

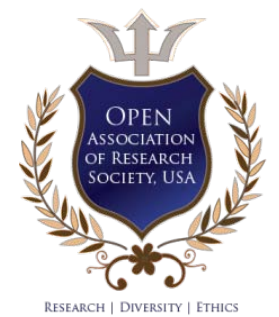

(c) 2020. Pastory, S. T, Francis, H. S \& Temu, G. S. This is a research/review paper, distributed under the terms of the Creative Commons Attribution-Noncommercial 3.0 Unported License http://creativecommons.org/licenses/by-nc/3.0/), permitting all noncommercial use, distribution, and reproduction in any medium, provided the original work is properly cited. 


\title{
Burgeoning of Commercial Ornamental Plant Nurseries in Dar es Salaam City: Challenge and Future Prosperity
}

\author{
Pastory, S. ${ }^{\alpha}{ }^{\alpha}$, Francis, H. S ${ }^{\sigma} \&$ Temu, G. $S^{\rho}$
}

\begin{abstract}
Commercial ornamental nurseries are popping up everywhere in the city of Dar es Salaam. However, as the city urbanizes, the commercial ornamental nurseries are confronted by several challenges of which are inadequately explored and documented. This research examines challenges, problems and explains the future prospects of commercial ornamental nurseries in the city of Dar es Salaam. The study adopted the case study design where the method for data collection relied on in-depth interviews and observation. Results revealed that ornamental plant dealers face several challenges such as; unsecured land tenure, which threaten the prosperity of the commercial ornamental nursery practices. Problems encountered are those related to plant pests, diseases management and inaccessibility of water for irrigation. On the other hand, commercial ornamental dealers get little support from the responsible city authorities in access land and management of pest and diseases. The study recommends that success of commercial ornamental nursery industry needs more support from different actors and policies together with capacity building among the commercial ornamental dealers.
\end{abstract}

Keywords: commercial ornamental nurseries, challenges, future prosperity.

\section{INTRODUCTION}

( ommercial ornamental nurseries are one among the informal growing sector in the urban areas of developing countries and it employs the youth who hardly access formal employment. A study by REPOA (2007), reported that more than $50 \%$ of the youth in Tanzanian urban are employed in the informal sector. According to Magigi (2013) more than 40\% of people in the Dar es Salaam city undertake their activities in the informal sector including urban agriculture. The commercial ornamental nurseries are one of the informal sector activities widely practiced in Tanzanian cities and urban areas including Dar es Salaam City (Liljestrom \& Persson, 2014).

Despite commercial ornamental plants nurseries taking being place in the informal sector, they play a vital role in greening the city (Hassan \& Mombo, 2016). The dealers of ornamental nurseries provide flowers which are used for aesthetical purposes (Akintoye et al, 2011). Furthermore, those dealers

Author a: Sokoine University of Agriculture Morogoro, Tanzania. e-mails: pastory.thomas@sua.ac.tz,pastosalva5@gmail.com Author $\sigma \rho$ : Institute of Rural Development Planning (IRDP) Dodoma. provide fruit trees which have motivated people in the peri-urban areas to grow fruit trees (Hassan \& Mombo, 2016 \& Lau, 2013). The fruits trees are important for food security and greening and beautifying the city environment (Osawaru et al, 2015).

Commercial ornamental nurseries do not only support the green urban environment and food security but also provide employment opportunities to youth and needy women in the urban areas. Ornamental tree nurseries offer employment opportunity to urban residents around the world and trends forecast show a promising market for this business (Di Vita, 2015). As a considerable number of youths have been employed in this sector, youth unemployment and income generation challenges have somehow been reduced (Abreu et al, 2009 \& Bishoge, 2018).

Despite the roles played by commercial ornamental being diverse, problem associated with it have been reported not only in developing countries but also in developed nations. For instance, in the United States of America, management of ornamental plants is less institutionalized compared to the rest of food crop production industry (Daughtrey \& Benson, 2005). It is reported that the ornamental plant growers do not enjoy the same governmental subsidies in comparison to nonornamental plant (Ibid). In Africa, several challenges have been noted. In Nigeria, the study by Adeduntan (2015) show that there is inadequate access to land by ornamental nursery dealers growers. In Kenya, the development activities such as the expansion of roads interfere with the existing nurseries along the major road reserves (Otiso, 2018).

In Tanzania, most of the government officials are not committed to support local ornamental plant nurseries simply because the accrued value of the enterprise cannot easily be expressed in monetary values which have an impact to city or national economy (Mg'ong'o, 2004 \& Hassan \& Mombo, 2016). In the similar note, Bishoge et al. (2017) noted that there is less recognition of the ornamental plant dealers by the government authority. Such inadequate recognition has hampered ornamental nursery dealers from accessing basic services as well as land. Furthermore, Bishonge and others noted that the ornamental dealers have a limited knowledge in managing the whole activities related to nurseries and growth of ornamental plants. 
However, the argument by Bishonge et al based from scientific research, some of the ornamental nurseries still exist and are rapidly emerging in the cities.

There has been substantial policy development and implementation toward managing urban issues such as; green spaces, human settlements, flooding and other many issues. United Nations in the new urban agenda advocates the nations to integrate policies that support green space in urban areas (United Nations, 2017). The UN Habitat encourages the development of policies that take into consideration the green spaces (Andersson, 2016). These international agencies believe that habitats or settlement without greening is hardly habitable. In 1990s, the Sustainable City Programme (SCP) gained acceptance globally as it encouraged collective efforts of different actors in addressing pertinent urban issues including solid wastes, urban renewal, open spaces mentioning but a few. In Tanzanian context, from SCP the Urban Environment Management (EPM) was established in order to identify, sensitize and work on these issues to enhance environmental sustainability (Kasala, 2015). One the highlighted issues by EPM are the management of open space. However, open space includes the green processes by using plants that are produced in the ornamental nurseries; ornamental nurseries were not given much priority (Hassan \& Mombo, 2016). As the result, they emerged everywhere in the city wherever there was a space and the possibility to operate informally.

Dar es Salaam city is one among cities adopted EPM process so as to solve environmental problems in urban areas. Other initiatives adopted and implemented by Tanzania government include the enactment of the National Environmental Act, 2004; National Land Policy of 1995 and the Urban Land Act No.4 of 1999 and The Urban Planning (Urban Farming) Regulations of 2018. In line with these policy and legal frameworks, the Tanzanian government is taking initiative to formalize informal settlements of urban areas and offering informal business card for people engaging in informal activities. However, such initiatives seem to overlook land for commercial ornamental enterprise which provides green materials greening urban environment.

Despite less legal and policy document in Tanzania context, commercial ornamental nurseries are mushrooming everywhere within the CBD and in the peri-urban areas of the city. Yet, there is a limited formal information platform for discussing the future prosperity of these commercial ornamental nurseries. Then, what is the future prosperity of commercial ornamental dealers? Therefore, this paper examines the challenges, problems and future prosperity of ornamental dealers in Dar es Salaam city.

\section{il. Methodology}

The study adopted a qualitative research approach in order to unveil the feelings, understanding, thoughts and opinions regarding the challenges and problems encountered by commercial ornamental dealers. Moreover, it employed a case study because five cases were studied including, Mlimani city along Makongo-Juu Road; Temboni along Morogoro Road and Magari Saba along Mbezi to Kibamba Road both in Ubungo Municipality. Others include sites besides Tumaini University College and GMS industrial area along Mwenge to Coca-Cola Road in Kinondoni Municipality.

Thirty ornamental plants dealers were purposively selected particularly those who could provide first-hand information. Moreover, five Mtaa chairpersons, one agrovet dealer, one town planner, one environmental officer and one agricultural officer were interviewed using checklists.

Data were collected from the primary sources through the in-depth interview with ornamental plant dealers, Mtaa chairpersons and the officials. Secondary sources of data, particularly published papers were reviewed firstly to widen the understanding of the researchers on the topic and secondly to cite important information in order to enrich the discussion.

\section{ili. Results and Discussion}

\section{a) Access to land for commercial ornamental nurseries}

Land is the requisite factor for the existence and flourishment of ornamental plant nurseries in the city of Dar es Salaam. Commercial ornamental dealers follow number of steps to acquire land depending on the existing ownership over the land they are interested for their activity. In the visited sites for instance, some of the land is owned by institutions while others by individuals. 


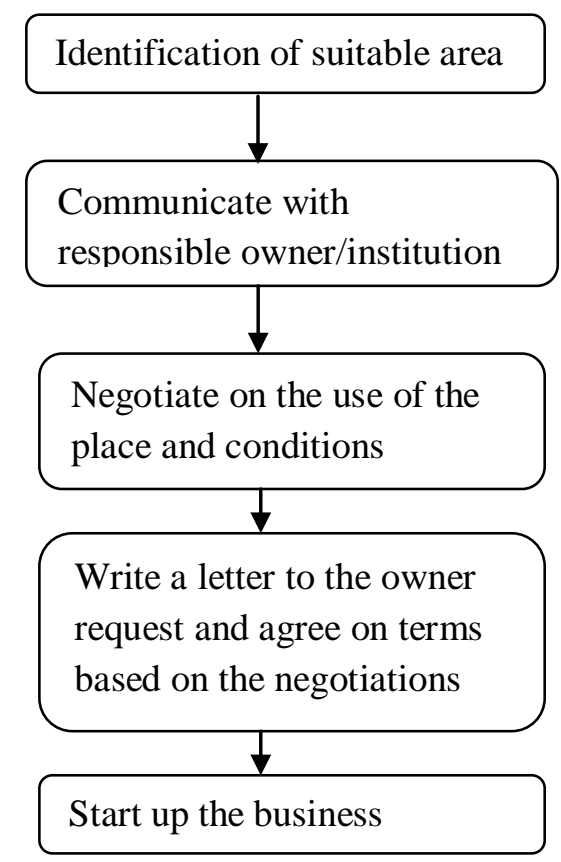

Figure 1: Steps followed to acquire and for ornamental nursery activities.

One of the respondents along Mlimani City nursery declared that places used for ornamental plant nursery are not accessed freely, one has to see the owner or responsible institution in order to request for the permission. However, before establishing the business, they first write a letter which presents their request and send it the owner of the land. Their request can be either accepted or rejected. When it is accepted, they are given conditions which they are obliged to adhere.

In the similar note, one of the respondents quoted saying that:

We wrote a letter to the University of Dar es Salaam management requesting a permission to use the two road reserves thinking that the University is the owner, instead the University directed us to the management of Mlimani City Shopping Mall who currently do manage the area, eventually permitted us but with some conditions".

One among the conditions was to ensure the general cleanness of the site used for such activity. Another condition given was that, they should be ready at any time to vacate the site wherever the area is needed by the management.

Similar conditions were given to Magari Saba ornamental dealers along Mbezi-Kibamba Road; although, this is a different site and owned by Tanzania National Roads Agency (TANROAD) The TANROAD told the ornamental nursery dealers to observe environmental cleanliness while undertaking their activities. The findings reveals that despite, land for ornamental nurseries being owned by different institutions, conditions given to the ornamental plant dealers and procedures to access such land are almost the same.

The most challenge encountered by the ornamental plant nursery dealers is the lack of security of tenure to support their existence in the site. Wherever owners need to use the area for other planned or emerging activities the nursery project ends up instantly. These findings reflect the study by Berry (2014) who points out that access to land by ornamental nursery dealers is not an easy task in rapidly urbanized cities. However frankly, ornamental plants are having more roles to play especially the green of urban environment. In other country like Nigeria also, access to land for ornamental activities is in adequate (Adeduntan, 2015), implying that there is no effort taken by the city authority to designate and allocate land for ornamental nurseries. When the ornamental dealers at Mbezi site were interrupted due to expansion of Ubungo- Kibamba road, they attempted to seek land elsewhere in the city. The squatted on un-built up public land while are keep on searching the land for their ornamental plants.

For instance, ornamental plant dealers located nearby the Tumaini University College along the Mwenge-Coca Cola Road were given a place by the Tanzania Rural and Urban Road Agency (TARURA) but condition that should be ready to vacate whenever the area is in need without any compensation. The condition of instant vacating given is tedious because it is not easy to secure area for short period of time. Some 
gardeners who suffered during the Ubungo-Mbezi road expansion squatted in the public land but three months later their nurseries were destroyed without a pre notice in-favour of government water project.

What happens along Ubungo-Mbezi in Dar es Salaam is not a new story in East Africa context, in Nairobi for example, the expansion of intra city roads involved the evictions of road reserve commercial ornamental dealers without any excuse and compensations (Otiso, 2018). In contrary, Franco et al. (2006) argued that commercial ornamental needs to be recognized in urban land use development projects in order to support the future of ornamental nursery projects. In some countries like Cuba and China, city authorities recognize the importance of ornamental nurseries and landscaping projects hence it area has been included in the design of detailed plan (Zeeuw et al., 2000 \& Lau, 2013). However, the city environmental officer acknowledged that in Tanzania little attention has been paid by urban authority to support ornamental nursery because it is thought that it is an enterprise which can operate privately. Despite ornamental nursery being the primary components for greening the city environment, its operation and management is not heartily supported and it seems to be not a city authority priority like health, water services, education and infrastructure development. All these have retarded efforts behind its prosperity.

\section{b) High urban land price}

The land value in Dar es Salaam city has increased because of increased population and high demand for residential and commercial plots As a result urban land use with higher economic merits are given priority in land use planning. Access to land by low income groups in urban areas remain uncertain due to high prices which do not reflect low income earners' budget like ornamental commercial dealers.

With this reason, few commercial ornamentals do rely on road reserved land to undertake such activity. Scholars Dearbornet \& Kark (2010) argue expensive land price in cities have discouraged majority land owners to put interest to commercial cultivars rather prefer other land uses like residential and commercial activities. Apart from high land price and lack of security of tenure, ornamental plant nursery requires good location free from interferences from other anthropogenic activities. However, this condition did not prevail to the ornamental nursery nearby Mwenge Minibus Stand because of the interferences from petty traders. In the discussion with some of the respondents who formally used area that area reported that because of interference of petty traders, they had to struggle searching for another site which destined them to the road reserve opposite GSM industrial area along Mwenge-Coca Cola Road.

One of the respondents in the discussion had this to say:

We had to leave the area because petty traders were not respecting our project they use to step on our seedlings, destroying them and even sometimes stealing them that made us find another place".

c) Access to water by commercial ornamental nursery dealers

Water is very necessary for the growth of plants as well as in the manufacturing of food via photosynthesis and also in the transportation of minerals and food for the plant. Ornamental plant nursery dealers from the visited sites access water from different sources to supplement rain water during dry season as shown in table 1.

Table 1: Access and sources of water by commercial ornamental nurseries

\begin{tabular}{|c|l|l|}
\hline S/n & \multicolumn{1}{|c|}{ Commercial nursery sites } & \multicolumn{1}{c|}{ Sources of water } \\
\hline 1 & Mlimani city & $\begin{array}{l}\text {-Waste water discharged from road side drains. } \\
\text {-Water discharged from the leakage of city water supply } \\
\text { authority (DAWASA). }\end{array}$ \\
\hline 2 & Beside Tumaini University Collage & $\begin{array}{l}\text {-Waste water discharged in road side drains from the nearby } \\
\text { residences. } \\
\text {-Sometimes do buy water from water vendors. }\end{array}$ \\
\hline 3 & Along GMS Industrial area & $\begin{array}{l}\text {-Waste water discharged in road side drains from the } \\
\text { industrial area and nearby residences. }\end{array}$ \\
\hline 4 & Temboni along Morogoro Road & $\begin{array}{l}\text {-Formal connection of water from the city water supply } \\
\text { authority. } \\
\text {-Water from shallow well dug out in the nearby water streams. }\end{array}$ \\
\hline 5 & Magari-Saba & \begin{tabular}{l}
-Water from shallow well dug out in the nearby water streams. \\
\hline
\end{tabular}
\end{tabular}

Source: Field data, 2019.

Like other sites, the Mlimani City use water from different sources including leakage from the Dar es Salaam Water Supply and Sanitation Authority (DAWASA) pipe locate underneath the site. Some are connected to DAWASA as the main supplier of water in the city where those connected do pay monthly bill amounting to 1,670TZS per cubic meter of water. Other sources include unclean water from road side drains, however commercial ornamental at Tumaini University and GSM site use drain water discharged from the 
nearby industries and waste water from nearby residential areas. Although some commercial ornament dealers use dirty water discharged from the industry and nearby residential houses, none have complained on the negative effects of such water to the garden plants. The use of reclaimed water is however, not a new phenomenon as it is also used in the United States of America for irrigation purposes (Haering et al., 2009); however, it is recommended that such water have to be treated to reduce infections. Again, during dry season most of ornamental dealers do buy water from street vendors at a price of 200TZS per 20 litters bucket. During the dry and drought seasons, only those plants which are less tolerance to drought are irrigated. Barbe et al. (2017) observed shortages of water supply for domestic uses in the informal settlement in Dar es Salaam City and such shortage also face ornamental nursery business.

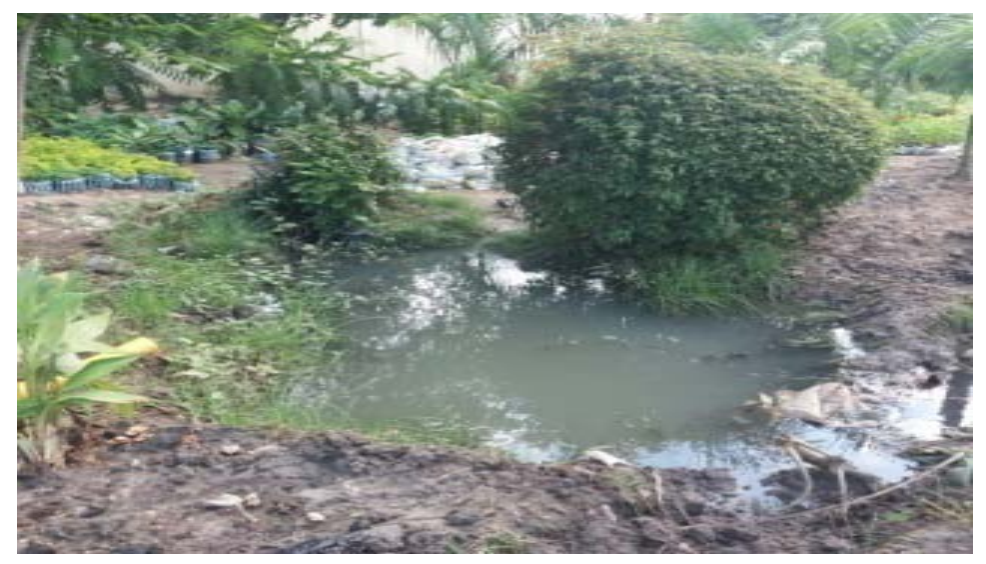

Source: Field survey, 2019.

Plate 1: Water source at Mlimani city shopping-mall nursery

d) Access to seeds and plant material for propagation

Seeds and other propagating materials such as flower and shrubs cuttings and suckers are important for the sustainability of ornamental plant nurseries (Dehnen et al, 2007). Seeds used by gardeners are both exotic and native species collected from various parts of the country. According to the interview, the gardeners collect the ornamental plant seeds and propagating materials within and outside the city and multiplied them through propagation techniques by some experienced gardeners. However, the findings revealed that people who used work as gardeners in foreign embassies and catholic churches located in Dar es Salaam are the ones who brought exotic spices of ornamental materials to nursery dealers. Some seeds of turf grass species like Brazilian are rarely sold in some shops at Kariakoo but most of them are locally collected. In order to ensure the supply of diverse ornamental plant species, some of the commercial ornamental plant garners have established the gardening network with commercial other ornamental dealers from other Tanzanian regions including; Tanga, Iringa, Morogoro, Mbeya and Arusha. However, not all plants from Tanzanian those regions perform better in the hot climate of Dar es Salaam and most of them already contain pest and diseases infestations According to one of the ornamental dealer adjacent Tumaini University argued that their interaction with other dealers outside Dar es Salaam help them share gardening experience, challenges and opportunities though mobile phones and sometime through face to face conversation. This implies that there is no formal arrangement and ways for gardeners to access improved seed for their nurseries (Magigi, 2013).

\section{e) Management of insect pest and disease}

Management of insect pest and diseases are essential aspect for the success of commercial ornamental nursery particularly in tropical countries like Tanzania as they have considerable effects in reducing quality and quantity of produce. This normally happen when choosing pest and disease resistant species as a preventive measure. Sometimes ornamental dealers spray pesticides as a control measure for the affected plants, thus, timely availability of inputs is very crucial (Magigi 2013). At Mlimani city nursery, the pests and diseases were not common, however, gardeners reported that, usually use to consult agricultural extension officers wherever they notice signs of insect pest and diseases. One of the agrovet-dealers interviewed said that; normally offer them with pyrethroids pesticide which is not effective for all types of insect pests. The study also revealed that, at Tumaini University College nursery site, the most common pest reported was aphid. Gardeners attempt to control it using Malathion pesticide. Nevertheless, respondents further reported that such pesticide is sold at higher price almost $30,000 T Z S$ per $100 \mathrm{ml}$ which is less effective for a single application, unless it is applied twice or thrice in a month.

At the GSM site, the nursery is affected by various pests and diseases. However, the gardeners do not know the type of the disease in English; rather describe the symptoms of the disease in Swahili 
language to agrovet dealers. In this incidence, various chemicals and pesticides are used based on the way are directed by agrovet-dealers to pests and diseases. According to one of the respondents around Tumaini University, ornamental dealers manage to name the pesticides in Swahili language as Digo, Carret, Ninja, Vitashield and Booster. The respondents further reported that normally booster is used to improve the health of the plant as well as making them greener. However, it is reported that, pest and diseases to plants are serious problem noted during the discussion with youth at Temboni site. Yet, youth undertaking commercial ornament activities are not knowledgeable with pests and diseases, they normally observe changes and physical abnormalities that affect normal plant growth and thereafter take the affected part of the plant to the agrovet dealers to seek for advice and how to deal with such problem. The most common diseases mentioned include fungal and bacterial disease with no specification of a particular disease. The commonly used chemicals and pesticides include Dasfarm, Profecron 720 EC and Farmguard 344SE as shown in plate 2. These findings are in contrary with the study carried out in Nigeria by Akintoye et al. (2011) pointed out the common insect pests of ornamental nursery including termites, white flies, stem bore and aphids while the diseases are root rot, powdery mildew, swollen shoot, leaf blight and stem bore.

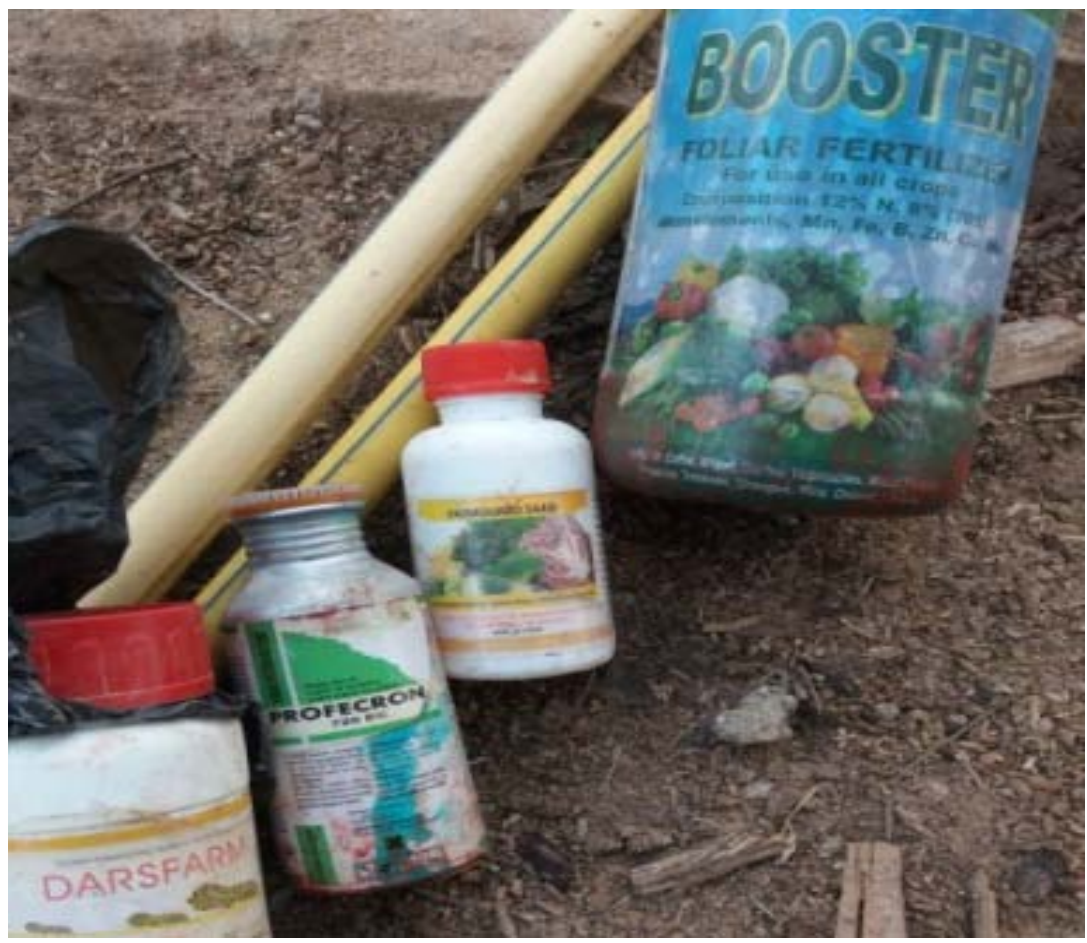

Source: Respondents interview, 2019.

Plate 2: Pesticides used in ornamental plant nurseries

\section{f) Marketing for ornamental plants}

Marketing is a very crucial aspect of any business. Market always sustains any business including production and selling of ornamental plants (Hsieh, 2001). Despite market being important, findings of this study show that commercial ornamental nurseries have no permanent customers of their nursery products, customers are coming from different places of the city. According to one of the respondents at Mlimani city, common buyers are the road passersby, those in car driving, owners of big hotels, commercial buildings and residential houses. Other customers include primary and secondary school as well as university management, who buy and planting them in the outdoor environment within their residences or campuses. Currently, some ornament dealers have started to propagate fruit trees such as mango, guava, pawpaws and citrus, all these are sold to different customers. The fruit trees are highly sold to customers compared to typical ornamental plants because of its possibility to offer double rewards such as food and ornamentation (Bishoge, 2018).

Commercial ornamental dealers generally have no reliable market as may stay for some days or a week or more without selling any plants, but when customers come do compensate those days stayed without making any sell. The gardeners mostly sell the nursery products during rainy season. According to one of the respondents at the Mlimani city the amount earned per month ranges from $600,000 T Z S$ to $900,000 T Z$ with an average of 20,000TZS and 30,000TZ a day respectively per person (by 2019, 1USD equates to an average of 
2,280 TZS). One of the respondents along Tumaini University College road reserve argued that the amount he earned is not enough to meet all his needs but he considers himself with better life in comparison to others with no any income generating activity. Another respondent at Temboni site reported to earn 600,000 TZS a week. Out of this amount earned per month, he saves one third of the earning as operational costs. The gardeners at this site work as a group while documenting the cost incurred in running the nursery and recording the amount earned as the group per month. The amount earned by garden how it is small; it justifies the finding by Barbe et al (2017) who reported that an enterprise has a possibility of reducing income and unemployment challenges.

\section{g) Knowledge acquaintance by commercial ornamental gardeners \\ Knowledge and experience are among major} factors behind success in any project. Likewise, ornamental plant production and management requires people with adequate knowledge obtained from formally recognized institution or practices (Barbe et al., 2017). In this study it was revealed that about $80 \%(n=30)$ receive no formal training in the ornamental nursery establishment and management. Most of them learn through practical and experiences. However, 10\% $(n=30)$ of the respondents attended a special training on plant propagation at Sokoine University of Agriculture while $10 \%(n=30)$ were informally working to individual persons (foreigners) who hired them, coached and instructed them on how to handle ornamental nurseries. As one respondent Mr. Abdala quoted saying that:

"When I was working at my boss flower garden, he trained me how to care the ornamental garden plants. After I left the work, I started operating my own small garden at Sinza ward before my friends joined me to establish nursery here at the Mlimani City Shopping Mall".

Another respondent reported that he was working in Mwanza region and when he arrived in Dar es Salaam he decided to continue with the ornamental commercial activities. Before he started this activity, he visited two different people in different places requesting for offering flower, shrubs and trees trimming service until when he established his own ornamental nursery in 2012. Later on, other youth who were his friends joined the business in 2015. Both of them receive neither financial nor training support from anybody/anywhere.

\section{h) Challenges}

Table 2 presents summary of the problems and challenges encountered by commercial ornamental dealers in the studied areas of Dar es Salaam city. Results from the discussion and in-depth interview show that the most pressing problem is lack of security of tenure followed by diseases and pests and lastly almost 5 interviewed persons claimed to have unreliable market.

Table 2: Ranking the challenges confronted by commercial ornamental plant gardeners

\begin{tabular}{cccc}
\hline S/n & Challenge & Frequency & Percentage (\%) \\
\hline 1. & Insecurity to land occupancy right & 30 & 44 \\
2. & Difficulties to access to water sources & 9 & 13 \\
3. & Inadequate assistance (technical/fund) & 7 & 10 \\
4. & Difficulties in marketing ornamental plants & 5 & 7 \\
5. & Diseases and pest management & 15 & 22 \\
6. & Plant materials and seeds inaccessibility & 2 & 3 \\
& Total & 68 & 100 \\
\hline
\end{tabular}

\section{i) Prospects}

Despite challenges facing commercial ornamental gardening, still there is hope and confidence of success among dealers (see table 3 ). In all interviews, respondents were free to mention their possible optimisms with regard to commercial ornamental nurseries; thus, the analysis and discussion of their claims are still vital. Table 3 present participants view and their future prosperity which may become true if some of the problems discussed can be resolved. In particular, the issue access to land for ornamental nurseries which scored $44 \%$ in challenge raking table. 
Table 3: Optimism of ornamental nurseries gardeners

\begin{tabular}{|c|c|c|}
\hline $\mathrm{S} / \mathrm{n}$. & Prospects & Remarks \\
\hline 1. & $\begin{array}{l}\text { Short term lease of vacant public land } \\
\text { located close to water sources and } \\
\text { road junctions. }\end{array}$ & $\begin{array}{l}\text { Temporally lease utilize idle land, gives gardeners income and can be } \\
\text { surrender when need by the owners }\end{array}$ \\
\hline 2. & Expanding their business & $\begin{array}{l}\text { Commercial ornamental gardening provides them a means of earning } \\
\text { income. }\end{array}$ \\
\hline 3. & Diversify their activity & $\begin{array}{l}\text { Strive to diversity ornamental garden activities as per wishes of their } \\
\text { customers. }\end{array}$ \\
\hline 4. & Seeking technical/financial support & $\begin{array}{l}\text { Visit city office and nation farmers exhibition day (Nane-nane day) for learning } \\
\text { more the management practice of their garden and secure fund where } \\
\text { wherever there is a possibility of doing that. }\end{array}$ \\
\hline 5. & Possession of informal business card & $\begin{array}{l}\text { The national business card granted for every year by the city authority will } \\
\text { make them more recognizable as private business people. }\end{array}$ \\
\hline 6. & $\begin{array}{l}\text { Grow ornamental plants adoptive to } \\
\text { local environment }\end{array}$ & $\begin{array}{l}\text { Grow ornamental resistance to drought or pest/disease subject to the advice } \\
\text { provided by consulting experts (whenever possible). }\end{array}$ \\
\hline
\end{tabular}

Source: Respondents interview, 2019.

The survival and the success of ornamental plants depend on the hopefulness of gardeners from the city authority. Therefore the information from Table 3 provides base information during debating and making decisions of urban land use and supporting ornamental plants nurseries in the cities.

\section{Conclusion}

The commercial ornamental nurseries are the main suppliers of ornamental and edible plants in the urban areas. Its values and importance are not restricted to income generation but also in beautifying and greening the urban built-up environment. Apart from these few mentioned values, the enterprise is confronted by number of problem and challenges such as; inaccessibility of land for establishment of nurseries and difficulties in their management practices. The possibility of gardeners to access to land lies within the capacity of city and urban authorities, but the decision in-favour of land for ornamental nurseries establishment seems to be expostulated in land use development decisions; hence, given less attention and priority. The values provided by ornamental nurseries are generalized in some legal and policy documents such as land policy, environmental policy and urban planning act but practically, ornamental gardening practices seem to take place in their absence. Agricultural extension services are mostly confined on food crops production and management; in a very rarely case such services are extended to ornamental plant garners. Moreover, limited source for water for irrigating the ornamental garden has exacerbated garden management problems particularly during the dry seasons. All these challenges and problems hamper the future prosperity of commercial ornamental gardens. Hence, subsequently the enterprise is likely to disappear and the values gained from it will nowhere be found and accommodated in our cities.

\section{ACKNOWLEDGEMENT}

The data of this study was collected from different commercial ornamental dealers in Dar es Salaam city and some selected city officials. Thus, authors would like to thank all participants who agreed to offer their time and provide us with information necessary for study. Authors contributed some amount of money to finance the whole process of conducting the study including field trips and interviews.

\section{References Références Referencias}

1. Abreu, P. P., Souza, M. M., Santos, E. A., Pires, M. V., Pires, M. M., \& de Almeida, A. A. F. (2009). Passion flower hybrids and their use in the ornamental plant market: perspectives for sustainable development with emphasis on Brazil. Euphytica, 166(3), 307-315.

2. Adeduntan, S. A. (2015). Contribution of some ornamental plants to the socio-economic development of urban household in Akure metropolis. African Journal of Agricultural Research, 10(4), 264-268.

3. Akintoye, H. A., Idowu, O. O., Olufolaji, A. O., Adebayo, A. G., Olatunji, M. T., Aina, O. O., \& Shokalu, A. O. (2011). Prospects and challenges of floriculture business in Nigeria. European Journal of Social Sciences, 19(3).

4. Berry. A. M. (2014). Expanding the Use of Vacant Land for Urban Agriculture in Champaign. MSc. Thesis at the University of Illinois.

5. Bishoge, O. K., \& Suntu, S. L. (2018). The Opportunies of Urban Horticulture for Poverty Alleviation in Dar es Salaam city, Tanzania-A Case of Ubungo Municipality. Journal of Food, Nutrition and Agriculture, 1(1), 12-16.

6. Daughtrey, M. L., \& Benson, D. M. (2005).Principles of plant health management for ornamental plants. Annu. Rev. Phytopathol., 43, 141-169. 
7. Dearborn, D. C., \& Kark, S. (2010). Motivations for conserving urban biodiversity. Conservation biology, 24(2), 432-440.

8. Dehnen-Schmutz, K., Touza, J., Perrings, C., \& Williamson, M. (2007).A century of the ornamental plant trade and its impact on invasion success. Diversity and Distributions, 13(5), 527-534.

9. Di Vita, Giuseppe, Valeria Allegra. and Alfonso Silvio Zarba(2015). Building scenarios: a qualitative approach to forecasting market developments for ornamental plants. International Journal of Business and Globalisation 15 (2): 130-151.

10. Franco, J. A., Martínez-Sánchez, J. J., Fernández, J. A. and Banon, S. (2006). Selection and nursery production of ornamental plants for landscaping and xerogardening in semi-arid environments. The Journal of Horticultural Science and Biotechnology, 81(1), 3-17.

11. Haering, K., Evanylo, G. K., Benham, B. L., \&Goatley, M. (2009). Water reuse: Using reclaimed water for irrigation[http://www.pubsext.vtedu] site visited on 01/09/2019.

12. Hassan, A. and F. Mombo.(2015). Urban community's participation in conservation of open spaces in Dar es Salaam city, Tanzania. [htpp://wwwsciencepublishinggroup.com/j/jijnrem] Site visited on 08/11/2019.

13. Hsieh, S. C. (2001). Taiwan Assisted Flower Production and Marketing in Paraguay. ICDF report.

14. Kasala, S. (2015). A return to master planning in Dar es Salaam: A misconception of the theory of paradigm shifts?. Global Journal of Human-socialscience: $B, 15(2), 1-8$.

15. Lau, H. L. (2013). Evolution of Urban Agriculture in Hong Kong: Stepping Towards Multifunctionality (Doctoral Dissertation, Chinese University of Hong Kong).

16. Liljestrom, C., \& Persson, M. (2014). Development of green space in Dar es Salaam, Tanzania. [http:www.stud.epsilon.slu.se]. Site visited on 02/08/ 2019.

17. Magigi, W. (2013). Urbanization and its impacts to food systems and environmental sustainability in urban space: Evidence from urban agriculture livelihoods in Dar es Salaam, Tanzania. Journal of Environmental Protection, 4(10), 1137.

18. Mng'ong'o, O. S. (2005). A browning process: The case of Dar es Salaam city (Doctoral dissertation, KTH). Mng'ong'o, O. S. (2005). A browning process: The case of Dar es Salaam city (Doctoral Dissertation, KTH, Royal Instate of Technology).

19. Osawaru, M. E., Ogwu, M. C \&Gbefue, D.(2015). Survey of Ornamental Gardens in Five Local Government Areas of Southern Edo State, Nigeria (www.researchgate.net/publication) Accessed on $5^{\text {th }}$ July, 2019.
20. Otiso, K. M. (2002). Forced evictions in Kenyan cities. Singapore Journal of Tropical Geography, 23(3), 252-267.

21. Research on Poverty Alleviation (REPOA) (2007) (www.repoa.or.tz/repoa) Site visited on 16/10/ 2019.

22. United Republic of Tanzania (URT), (1995), National Land Policy, The Ministry of Lands, Housing and Human Settlement Development, Tanzania.

23. United Republic of Tanzania (URT). (2007). Land Use Planning Act, 2007. Government Printer, Dar es Salaam.

24. United Republic of Tanzania (URT). (2018). The Urban Planning (Urban Farming) Regulations, The Ministry of Lands, Housing and Human Settlements Development, Tanzania.

25. Zeeuw, H., Guendel, S., \& Waibel, H. (2000). The integration of agriculture in urban policies. Growing cities, growing food. Urban agriculture on the policy agenda, 161-180. 